\title{
COMBATES PELA MEMÓRIA: BRASIL NUNCA MAIS VERSUS BRASIL SEMPRE*
}

\author{
Cristiane da Silva Oliveira \\ PPPGMLS/UESB \\ José Alves Dias \\ PGMLS/UESB
}

\section{A construção do aparato repressivo}

A repressão aos opositores da ditadura militar no Brasil foi engendrada no alto comando das Forças Armadas Brasileiras (FAB) e executada pelos principais órgãos de segurança do Estado que detinham o monopólio da violência. Para tanto, a Lei de Segurança Nacional (LSN), em conformidade com a Doutrina de Segurança Nacional e Desenvolvimento (DSND), foi o instrumento jurídico que fundamentou a empreitada anticomunista no Brasil, assim como, os Atos Institucionais e Complementares, posteriormente incorporados ao texto constitucional promulgado em 1967, suprimiram os direitos de todos os que se insurgiram contra a tecnocracia militar que passou a executar os propósitos da burguesia no Brasil. ${ }^{1}$

Joseph Comblin (1978) ressalta a importância de compreender o conceito de desenvolvimento da DSN, afirmando que o desenvolvimento é relacionável à segurança:

O desenvolvimento de que estamos tratando é intimamente ligado à segurança. Nunca é estudado fora desta estreita associação com à segurança. É um complemento de segurança. É inútil apelar para outras ciências a fim de melhor compreendê-lo. [...] Castello Branco exprimiu essa estreita relação sob a forma de uma causalidade recíproca: “A inter-relação entre o desenvolvimento e a segurança faz com que, por um lado, o nível de segurança seja condicionado pela taxa e o potencial de crescimento

${ }^{*}$ DOI - 10.29388/978-65-86678-62-8-0-f.59-76

${ }^{1}$ Em 1967, logo após a posse presidencial do general Artur da Costa e Silva, passou a vigorar uma nova Lei de Segurança Nacional (LSN) que converteu a Doutrina de Segurança Nacional e Desenvolvimento em legislação, diferenciando-se da Lei 1.802, de 1953, ao substituir as definições dos crimes contra o Estado pelos crimes contra a "Segurança Nacional" com ênfase na sua internalização. Caracterizou-se, também, por sujeitar todos os cidadãos a jurisdição militar e em responsabilizá-los pela segurança da nação que, de acordo a nova lei, vivia a constante ameaça da "infiltração comunista" e do eminente risco de eclosão de uma guerra de caráter psicológico e revolucionário. 
econômico, e, por outro lado, o desenvolvimento econômico não possa se efetuar sem um mínimo de segurança". O desenvolvimento foi introduzido na Doutrina da Segurança Nacional. E o trabalho teórico das doutrinas consistiu em pôr em evidência os laços entre segurança e desenvolvimento (COMBLIN, 1978, p. 66).

Em 1949, com os desdobramentos geopolíticos da II Guerra Mundial, foi criada a Escola Superior de Guerra (ESG) com a finalidade de realizar análises conjunturais e instruir politicamente os cadetes nas Forças Armadas diante da participação do país no bloco ocidental liderado pelos Estados Unidos. No que tange a ação política da referida escola, a mesma promoveu a integração dos interesses entre diferentes setores da classe dominante articulando-os diretamente com as Forças Armadas Brasileiras (FAB).

A Doutrina de Segurança Nacional e Desenvolvimento foi um elemento essencial para formação intelectual dos educandos da ESG e, como desdobramento, o conceito de Segurança Nacional incidiu numa crescente mobilização dos mesmos para a defesa interna e o desenvolvimento do potencial econômico do país, como também.

A Escola Superior de Guerra, portanto, foi um centro de estudos e pesquisas voltado para a formação de civis e militares que desempenhavam funções relativas à segurança e ao desenvolvimento do país. Eliézer Rizzo de Oliveira (1976) avalia o seu acentuado desempenho e a caracteriza como um aparelho ideológico do Estado.

Os militares foram os principais propagadores da Ideologia de Segurança Nacional no período ditatorial e diante disso, Oliveira (1976) aponta dois "canais" históricos entre o pensamento autoritário e a Doutrina de Segurança Nacional: todos os pracinhas que participaram da Força Expedicionária Brasileira (FEB), da formação da Escola Superior de Guerra, do Clube Militar e da campanha do petróleo, além de contemporâneos, são oriundos de uma mesma formação autoritária e a produção intelectual de alguns deles evidencia isso.

Ainda segundo o cientista social e político supracitado, a associação entre a segurança do país e o pensamento autoritário internalizou o conceito "guerra interna" e assim promoveu a submissão das atividades básicas da nação à sua política de segurança. Os interesses e aspirações nacionais foram definidos nos Objetivos Nacionais Permanentes (ONP) e quaisquer impedimentos existentes para atingir as metas de segurança estabelecidas seriam supridos com Objetivos Nacionais Atuais (ONA).

O mesmo autor ainda pontua que o poder político definiu-se de tal modo nas Forças Armadas Brasileiras que elas assumiram as funções centrais 
do Estado, desde o gerenciamento da economia até os rumos e limites do sistema político. Diante disso, posicionaram-se no contexto do golpe de março de 1964 como um instrumento estratégico de manutenção da "fronteira interna ao socialismo" no intuito de conter os movimentos populares e de preservar os fundamentos do Estado capitalista no Brasil.

Dreifuss e Dulci (1984), ao examinarem sobre a referida instituição militar e o papel político por ela desempenhado após 1964, constataram que as Forças Armadas Brasileiras, norteadas pelas normas do bloco histórico capitalista e aliançadas com os Estados Unidos:

[...] assumiram a promoção do Desenvolvimento pela garantia da Segurança, na forma definida pelos ideólogos da Escola Superior de Guerra e dentro das condições da lógica da coerção. Sua política voltava-se para a permanência do "poder revolucionário" de modo a fazer do país, por volta do fim do século, uma potência reconhecida mundialmente. Esse projeto nacional demandava "estabilidade política"; a democracia seria o produto final de uma evolução controlada de cima. Um conceito autoritário de poder foi então adotado como fundamento, como técnica e forma organizacional do regime, cristalizando-se no Ato Institucional $n^{\circ} 5$ (DREIFUSS; DULCI, 1984, p. 143).

Maria Helena Moreira Alves (1989) concluiu que a ditadura militar se conformou sob a égide da Doutrina de Segurança Nacional que possuía uma tríplice função: identificar uma ideologia que informasse e moldasse as estruturas de Estado; elaborar e impor formas de controle à sociedade civil e criar um projeto de governo economicamente capitalista e politicamente autoritário.

De forma semelhante, Joseph Comblin (1978), ao caracterizar os regimes de segurança nacional, ressalta que a sua característica mais significativa é que, “[...] o presidente exerce seus poderes através de dois setores paralelos. Um deles é público: o governo e a administração; o outro é secreto: é o conjunto dos Serviços de Informação, mas também serviços de ação" (COMBLIN, 1978, p. 82).

Segundo Florestan Fernandes (1982), o funcionamento real da ditadura parte da impossibilidade de dissociar o Estado, o governo e a sociedade, pois, caso isso ocorresse:

[...] não poderia entender as origens, os limites e as funções do Estado, e como este, enfim, é determinado socialmente e se transforma historicamente, e como o governo surge e cresce como uma forma política destinada a reproduzir, a defender e a impulsionar a evolução progressiva (re- 
gressiva) de certo tipo de Estado (FERNANDES, 1982, p.10).

Em síntese, o Estado de Segurança Nacional (ESN), assim denominado por sua vinculação à Doutrina de Segurança Nacional (DSN), tinha como propósito fazer do Brasil uma potência reconhecida por todo o mundo. De acordo com as reflexões de Alves (1989), esse objetivo deveria ser alcançado por meio do papel singular que a economia brasileira vinha desempenhando no sistema econômico mundial com a penetração do capital internacional desde meados da década de 50, do século XX.

Tal fato estabeleceu uma aliança entre o capital multinacional, o capital nacional associado-dependente e o capital do Estado, que deveriam proporcionar um desenvolvimento capitalista associado dependente e, por isso mesmo, sem condições de atender as necessidades materiais básicas da população. Diante dos antagonismos sociais oriundos dessa distorção econômica cabia ao Estado defender os interesses dominantes e suprimir quaisquer manifestações contraditórias.

\section{Brasil: um país de antagonismos}

Nos dias subsequentes ao golpe 1964 iniciou-se um processo de "higienização" no país que atingiu, indiscriminadamente, indivíduos oriundos das mais diversas matrizes políticas. O principal objetivo foi destituir dos cargos públicos quaisquer pessoas que ameaçassem a vigência do poder usurpado com a deposição do presidente eleito João Goulart. Para alcançar tal propósito foi criado, no mesmo ano, o Serviço Nacional de Informações (SNI) no intuito de espreitar a sociedade em geral e identificar aliados do governo anterior. Para garantir o sigilo dos atos escusos praticados pela autocracia militar decretou-se, em 1967, a Lei de Imprensa que regulamentava a censura a periódicos, estações de radiodifusão, agências de notícias, bem como, a exibição de espetáculos e eventos de diversões públicas. Em paralelo, a propaganda oficial difundia uma imagem favorável do governo na tentativa de promover ideologicamente o consenso e camuflar as disparidades sociais. ${ }^{2}$

Nessa direção, o aparato repressivo do Estado estabeleceu uma engrenagem de controle para garantir a segurança nacional formada pelo Serviço $\mathrm{Na}$ cional de Informações (SNI) e a Operação Bandeirantes (OBAN). O primeiro atuou como catalisador de dados, por meio de ações de inteligência e espiona-

\footnotetext{
${ }^{2}$ Em 1970, o futebol promoveu o consenso nacional almejado pela ditadura, visto que, a alegria com o tricampeonato da seleção brasileira de futebol entorpeceu os torcedores ao mesmo tempo em que os insurgentes eram seviciados nos porões dos órgãos de repressão.
} 
gem, para subsidiar as decisões do Poder Executivo e suas ramificações repressoras. O segundo funcionou como uma central que agregava todas as forças militares e policiais com a finalidade de identificar, prender e exterminar os opositores na região Sul do país.

O SNI, cujo principal mentor intelectual foi o general Golbery do Couto e Silva, funcionou entre 1964 e 1990 e tinha alcance nacional e apoio financeiro de empresários anticomunistas que se reuniram no Instituto de Pesquisas e Estudos Sociais com o propósito de destituir o vice-presidente João Goulart que, após a renúncia de Jânio Quadros, assumiu o exercício do cargo em 1961. A OBAN, fundada em 1969, visava operacionalizar a repressão aos opositores embasada no Ato Institucional N. ${ }^{\circ}$ 5, editado no ano anterior. Sua estrutura compunha-se de indivíduos oriundos do Exército, da Marinha, da Aeronáutica, da Polícia Federal, das Polícias Estaduais e outros órgãos de segurança.

Para garantir o seu pleno funcionamento, o país foi dividido em áreas de segurança interna, sendo que em cada uma funcionava um Centro de Operações de Defesa Interna (CODI), que era chefiado por um comandante do Exército. O órgão era responsável pela coordenação das atividades coercitivas tendo suas ações e informações centralizadas para assessorar o Departamento de Operações Internas (DOI), órgão responsável pela prática do sistema repressivo, ou seja, o processamento capturas, interrogatórios, busca e de apreensão de matérias considerados subversivos. Conforme Alves (1989), o CODI contava, ainda, com o auxílio dos serviços do Centro de Informações do Exército (CIE), do Centro de Informações da Aeronáutica (CISA) e do Centro de Informações da Marinha (CENIMAR).

Do lado opositor, evidenciou-se a forte influência da experiência revolucionária cubana sobre as organizações clandestinas de esquerda que insurrecionaram em todos os países latino-americanos. Prova cabal disso foi a criação da Organização Latino-Americana de Solidariedade (OLAS) gestada após a Conferência Tricontinental de Solidariedade Revolucionária, que intuía abranger os objetivos comuns aos asiáticos, africanos e latino-americanos e ordenar a luta contra o imperialismo.

Assim, de acordo com Artêmio Soares Marques (2009), apesar das divergências políticas e de pensamentos, reuniram-se na ocasião delegações formadas por representantes dos partidos comunistas latinos e pelas mais diversas organizações de esquerda que compartilhavam de algum modo os ideais da Revolução Cubana.

A Conferência da OLAS ocorreu entre julho e agosto de 1967 e teve a finalidade de acoplar, ordenar e instigar a luta pela via armada contra o imperialismo norte-americano. Dentre os participantes brasileiros destacou-se a figura 
de Carlos Marighella que integrava, na época, o Partido Comunista Brasileiro (PCB), do qual não recebeu autorização para sua participação pelo fato do partido defender a luta por "vias democráticas". Marighella, imbuído do sentimento guerrilheiro, ao retornar ao Brasil desvencilhou-se do partido e fundou a Ação Libertadora Nacional (ALN).

No que se refere ao posicionamento da Igreja Católica, destaca-se que apesar de o alto clero ter sido um grande aliado para a derrubada do governo de João Goulart, promovendo forte campanha anticomunista, existiram religiosos e leigos que, motivados pelo sentimento humanitário, se sensibilizaram diante das lutas populares e arriscaram a própria segurança ao se enveredarem na luta contra a ditadura. Movimentos religiosos católicos, como a Juventude Universitária Católica (JUC) e a Juventude Operária Católica (JOC), uniram forças com outros setores da sociedade na luta contra a opressão vivida no país. Vários religiosos foram tidos pelo regime ditatorial como subversivos, comunistas, traidores da Igreja e da nação, tendo nessas acusações um álibi para a prática de tortura e assassinatos.

Para explicar a mudança de posicionamento da Igreja Católica no Brasil durante a ditadura militar, Scott Mainwaring (1983) assinala que essa mutação partiu de dois ensejos: primeiro, a crise enfrentada pela Igreja após II Guerra Mundial, ocasionada pelo fato da mesma não ter acompanhado as transformações da sociedade em geral; segundo, a luta política em vigor no país que induziu distintos "indivíduos e movimentos a uma nova visão de fé, profundamente preocupada com a justiça social e as classes populares." (MAINWARING, 1983, p. 48-49)

Em meio às intensas manifestações contrárias ao golpe de 1964 e à ditatura subsequente instalada, destacaram-se os estudantes secundaristas e universitários, especialmente quando, em março de 1968, durante uma ação policial ocorreu o assassinato de Edson Luís, no Restaurante Calabouço, no Rio de Janeiro. O ocorrido disseminou manifestações de protesto de vários setores sociais e a condução estudantil do funeral, do cortejo e da missa pesarosa intensificaram o repúdio à violência contra os jovens opositores.

Acerca da relação entre o Estado autocrático e o movimento estudantil, João Roberto Martins Filho (1986) afirma que esse último viveu mais profundamente o abalo entre o diálogo e a repressão,

Procurando tirar partido da desgastada figura do presidente Castelo Branco, que atraiu sobe si toda a insatisfação social diante do avanço do autoritarismo, os partidários de Costa e Silva procuraram enfatizar o advento de mudanças, basicamente no nível do discurso. Entretanto, em 
seu aspecto mais profundo, as promessas de "dialogo", [...] expressavam um nível mais relevante do processo de militarização: a contradição que então se tratava entre a "profissão de fé" liberal-democrática (inspirada no modelo norte-americano) e as práticas efetivas de progressiva militarização do Estado e "fechamento" de cena política. As instáveis relações entre o governo Costa e Silva e o movimento estudantil foram um dos sinais mais evidentes desse processo. Quando propunha o "diálogo", o regime fundamentava-se em suas esperanças de conseguir um apoio político às suas políticas no seio da classe média, e mesmo das classes trabalhadoras. Quando, por outro lado, reprimia ou proibia as manifestações estudantis, o governo militar dava vazão à tendência que cada vez mais se impunha de aprofundamento da militarização como pré-condição para o prosseguimento de sua política de desenvolvimento (MARTINS FILHO, 1986, p. 166-167).

Desse modo, o pesquisador acima citado reitera que a repressão do segundo governo militar brasileiro se antecipou à radicalização da oposição como pode ser verificado no fragmento complementar que se segue:

Com efeito, antes mesmo de surgirem os primeiros sinais de radicalização da luta popular e das práticas da esquerda, em 1968, setores importantes das Forças Armadas, designados em geral como a "linha dura" e que ocupavam postos-chave no governo Costa e Silva, já pareciam terse definido por uma estratégia de pressão em favor do "endurecimento" político. O movimento estudantil forneceu os principais pretextos para a sua atuação. Assim, a radicalização da direita militar mais extremada parece ter se antecipado a acontecimentos como as greves operárias de Contagem e Osasco, o emprego de táticas "foquistas" pelo movimento estudantil e o anúncio da adesão da esquerda à "luta armada". Ao longo de todo o período em questão, a "linha dura" atuou segundo uma linha básica: procurava criar situações de fato, em geral ações repressivas destinadas a produzir grandes repercussões contrárias, que obrigavam o governo a endurecer cada vez mais sua política. (MARTINS FILHO, 1986, p. 173-174)

Durante o ano de 1968, o movimento estudantil alcançou sua mais efervescente expressão contestatória, tendo à frente a União Nacional dos Estudantes (UNE) que, mesmo extinta logo após o golpe de 1964, continuou sendo um importante símbolo político da organização discente.

Todavia, em consequência da repercussão negativa da brutal repressão contra manifestantes indefesos nos acontecimentos em torno do restaurante universitário, o governo afastou provisoriamente os militares das ações ostensi- 
vas. Tal fato permitiu o acontecimento da passeata prevista para 25 de junho de 1968 que reuniu mais de cem mil pessoas em frente da Igreja da Candelária, no Rio de Janeiro e seguiu pelas principais vias da capital carioca em protesto contra a autocracia militar. Maria Helena Moreira Alves (1989) ressaltou a heterogeneidade da oposição que participou do ato:

[...] a própria composição da "Comissão dos Cem Mil" evidencia a natureza da aliança oposicionista: um representante de setores profissionais, dois representantes dos estudantes, um do Movimento das Mães pela Anistia e um padre representando a Igreja Católica. Tratava-se de uma comissão de negociação representando as classes médias, àquela altura em aberta oposição aos militares no poder e enfrentando a polícia nas ruas. O Estado de Segurança ficou mais isolado da sociedade civil; começava a fechar-se o círculo do poder. (ALVES, 1989, p. 119)

A ousada iniciativa de promover clandestinamente o Congresso Estudantil, em outubro daquele ano, no município de Ibiúna, São Paulo, foi desarticulada a prisão dos líderes e militantes presentes ao evento.

A mesma escritora pontua que o Congresso Nacional, por meio dos "parlamentares de oposição eleitos em 1966", exerceu um importante papel na acusação da ação repressiva do governo do general Castelo Branco. Providos de suas imunidades parlamentares os componentes de um grupo político ligado ao Movimento Democrático Brasileiro (MDB) expressaram-se na tribuna parlamentar com graves denúncias (ALVES, 1989, p. 128-129). Dentre os discursos, o do deputado Márcio Moreira Alves, proferido em 2 de setembro de 1968, teve singularidade de mobilizar uma parte considerável da sociedade para boicotar o desfile militar no dia 7 de setembro daquele mesmo ano como pode ser observado no conteúdo da aludida preleção:

\section{Sr. Presidente, Srs. Deputados,}

Todos reconhecem ou dizem reconhecer que a maioria das Forças Armadas não compactua com a cúpula militarista que perpetra violências e mantém este país sob regime de opressão. Creio ter chegado, após os acontecimentos de Brasília, o grande momento da união pela democracia. Este é também o momento do boicote. As mães brasileiras já se manifestaram. Todas as classes sociais clamam por este repúdio à polícia. No entanto, isto não basta. É preciso que se estabeleça, sobretudo por parte das mulheres, como já começou a se estabelecer nesta Casa, por parte das mulheres parlamentares da ARENA, o boicote ao militarismo. Vem aí o 7 de setembro. As cúpulas militaristas procuram explorar o sentimento profundo de patriotismo do povo e pedirão aos colégios que 
desfilem junto com os algozes dos estudantes. Seria necessário que cada pai, cada mãe, se compenetrasse de que a presença dos seus filhos nesse desfile é o auxílio aos carrascos que os espancam e os metralham nas ruas. Portanto, que cada um boicote esse desfile. Esse boicote pode passar também, sempre falando de mulheres, às moças. Aquelas que dançam com cadetes e namoram jovens oficiais. Seria preciso fazer hoje, no Brasil, que as mulheres de 1968 repetissem as paulistas da Guerra dos Emboabas e recusassem a entrada à porta de sua casa àqueles que vilipendiam-nas. Recusassem aceitar aqueles que silenciam e, portanto, se acumpliciam. Discordar em silêncio pouco adianta. Necessário se torna agir contra os que abusam das Forças Armadas, falando e agindo em seu nome. Creia-me Sr. Presidente, que é possível resolver esta farsa, esta democratura, este falso impedimento pelo boicote. Enquanto não se pronunciarem os silenciosos, todo e qualquer contato entre os civis e militares deve cessar, porque só assim conseguiremos fazer com que este país volte à democracia. Só assim conseguiremos fazer com que os silenciosos que não compactuam com os desmandos de seus chefes, sigam o magnífico exemplo dos 14 oficiais de Crateús que tiveram a coragem e a hombridade de, publicamente, se manifestarem contra um ato ilegal e arbitrário dos seus superiores. ${ }^{3}$

O teor do discurso do deputado foi conveniente aos interesses da "linha dura" que inflamou os ânimos dos quartéis ao distribuir cópias do mesmo entre os oficiais, desencadeando a indignação e um forte sentimento de ofensa à honra dos militares. Como resultado do ocorrido foi requerido o julgamento do parlamentar tendo sido o mesmo cassado por maioria de votos das duas casas legislativas.

As insurgências da oposição foram abruptamente abortadas com a edição, em 13 de dezembro de 1968, ou seja, um dia após da supracitada votação, do Ato Institucional $n^{\circ} 5$ (AI-5) deflagrando a fase mais aguda da repressão, uma vez que, "[...] em nome do anticomunismo, a Doutrina de Segurança Nacional, com sua ênfase na segurança interna, leva inexoravelmente ao abuso do poder, às prisões arbitrárias, à tortura e à supressão de toda liberdade de expressão" (ALVES, 1989, p. 27).

Com a imprensa emudecida, lideranças sindicais ou estudantis presas e torturadas e o acirramento repressivo após AI-5 a via pacífica foi conclamada inviável e parte dos opositores optou pela luta armada e, consequentemente, a clandestinidade. Os primeiros movimentos tiveram como propósito conseguir

\footnotetext{
${ }^{3}$ Discurso pronunciado em 2 de setembro de 1968, em sessão no Congresso Nacional, pelo deputado Márcio Moreira Alves. Disponível em: < $\underline{\text { https://www.marciomoreiraalves.com. }>\text { Acessa- }}$ do em 27 jun. 2017.
} 
armamento, munições e desapropriar bancos, no intuito de angariar fundos para manutenção das organizações. Porém, as ações mais destemidas desempenhadas pelas vertentes urbana da guerrilha, foram os sequestros de embaixadores e cônsules. ${ }^{4}$

A organização dos sequestros demonstrou a sagacidade revolucionária e, simultaneamente, incitou a coerção violenta do Estado aos que se opunham ao sistema ditatorial. A exacerbação repressiva, trucidando, torturando e apagando qualquer foco de resistência, retirou de cena ícones como Carlos Marighella, morto numa emboscada, em 1969, por agentes do Departamento de Ordem Política e Social (DOPS) coordenados pelo delegado Sérgio Paranhos Fleury, e do capitão Carlos Lamarca, executado, em 1971, por oficiais que integravam a "Operação Pajuçara", no interior da Bahia.

Em 1972, o Estado, por intermédio do SNI, descobriu um foco guerrilheiro ligado ao Partido Comunista do Brasil (PC do B) que atuava na divisa entre os estados de Goiás, Pará e Maranhão. Após a efetivação de várias operações militares, ocorridas entre os anos de 1972 e 1975, sendo que a terceira, designada Operação Marajoara, ocorrida entre 1973 e 1974, exterminou sistematicamente a Guerrilha do Araguaia. Além disso, as Ligas Camponesas que atuavam no país desde a década de 50, do século XX foram eliminadas com o mesmo rigor repressivo.

Ao verificar as instruções contidas no Manual Básico da Escola Superior de Guerra (ESG) (1992) constata-se que, de acordo com os ideais militares, no intuito de defender internamente a nação, o governo poderia adotar atitudes, medidas e ações de caráter preventivo, repressivo e operativo, a fim de superar a subversão. Verifica-se que o emprego da tortura na ditadura apoiava-se na forma específica assumida pela Ideologia de Segurança Nacional na América Latina, dentro do contexto da Guerra Fria, enfatizando a "segurança interna" em face da ameaça de "ação indireta" do comunismo.

Assim, preocupados com o crescimento dos movimentos sociais e a organização da classe trabalhadora, os teóricos da ditadura enfatizaram a ameaça da "subversão interna" e da "guerra revolucionária" supondo um "ataque indireto" e a ameaça de guerra subversiva ou revolucionária por parte da União

\footnotetext{
${ }^{4}$ Nos anos de 1969 e 1970 quatro sequestros afetaram a imagem do Estado em nível internacional diante dos constrangimentos diplomáticos causados com os raptos, os quais eram efetivados, em um primeiro momento, para atrair a atenção internacional para o que vinha acontecendo no Brasil, e, ao mesmo tempo, servia de moeda de troca pela liberdade dos líderes encarcerados e submetidos à prática da tortura. $\mathrm{O}$ primeiro sequestro foi o do embaixador norte-americano Charles Burke Elbrick, realizado em setembro de 1969. Em seguida, no ano de 1970, ocorreram os sequestros do cônsul japonês Nobuo Okushi, do embaixador alemão Ehrenfried Anton Theodor Ludwig Von Holleben e o do embaixador suíço Giovanni Enrico Bucher.
} 
Soviética, a qual recrutava seus combatentes entre a população brasileira. Tal fato tornava toda a população suspeita, pois era constituída, de acordo com a ESG, de potenciais "inimigos internos" que deviam ser controlados, perseguidos e eliminados. (OLIVEIRA, 1978)

A tortura, enquanto forma de aniquilação do opositor, emergiu da teoria do "inimigo interno" e proporcionou a criação de um aparato repressivo e de controle armado capaz de detectar as ameaças e eliminá-las. Paralelamente, propunha-se o fortalecimento econômico do país com o desenvolvimento capitalista subsidiado pelo imperialismo. Evidentemente, que a neutralização da oposição abriu caminho para a pilhagem das riquezas naturais e/ou produzidas pela classe trabalhadora.

\section{A denúncia da repressão em "Brasil Nunca Mais"}

"Brasil Nunca Mais" foi um projeto idealizado por religiosos e advogados que se dedicaram a reunir cópias de diversos processos que tramitaram pela Justiça Militar, entre abril de 1964 e março de 1979. Os resultados foram reunidos em seis tomos sendo que três deles se subdividem em mais de um volume.

A síntese da pesquisa foi resumida numa obra homônima, publicada em 1985, e abarca a origem histórica da ditadura militar e a organização e estruturação do Estado de Segurança Nacional (ESN), por meio de suas bases legais expressas nos atos legislativos, na institucionalização da tortura, na construção do aparato repressivo e da rede de informações. Nas partes subsequentes, os pesquisadores destrincham as principais formas de tortura e rastreiam as técnicas empregadas, a participação dos profissionais da saúde, as marcas psicológicas deixadas nas vítimas, as mortes e os desaparecimentos. ${ }^{5}$

$\mathrm{Na}$ obra citada acima, comparecem os estudantes e a UNE que, pela histórica luta em favor da qualidade do ensino no país, bem como, na defesa da democracia ou aderindo às reivindicações operárias, foram alvo prioritários da ditadura. Os depoimentos de João Luiz San Tiago Dantas Barbosa Quentel, 21 anos, e Manuel Domingos Neto, 22 anos evidenciam as mazelas provocadas aos oponentes, com a prática da tortura. Também estão presentes os profissionais de variados setores, representados pelo bancário Manoel Henrique Ferreira, 21 anos, e pelo professor Luiz Andréa Fávero, 26 anos. Em ambos os depoimentos se clarificam a participação setores médios que se opuseram a ditadura militar no Brasil, muitos dos quais acusados de aproximação ao governo de João Goulart, de atuar na difusão de propaganda considerada subversiva, de

\footnotetext{
${ }^{5}$ A versão integral e digital da pesquisa Brasil Nunca Mais está disponível no endereço eletrônico: < http://bnmdigital.mpf.mp.br/pt-br/ >
} 
tecer críticas às autoridades da ditadura imposta após a ação golpista de 1964 e/ou de denunciarem a operacionalidade do Estado em favor da manutenção e/ou reprodução do status quo dominante.

Todavia, como pode ser verificado em "Brasil Nunca Mais" (1985) não houve limites para a tortura durante o período autocrático no Brasil e ela foi aplicada, indiscriminadamente, a todos aqueles identificados genericamente como comunistas fossem políticos aliados do governo desposto de João Goulart, operários, estudantes, parlamentares do Movimento Democrático Brasileiro (MDB) ou militantes do PCB e suas dissidências.

A tortura não por finalidade somente provocar dor física, como também, sucumbir os indivíduos pela destruição moral e emocional ao romperem com seus limites. Muitos foram intimidados pelas sevícias e ameaçados com violência até o ponto confessarem crimes jamais cometidos:

Ao compareceram perante o Conselho de Justiça, muitos réus denunciaram como foram induzidos a assinarem depoimentos forjados, na fase do inquérito policial, como ocorreu com o professor Luiz Andréa Fávero, de 26 anos, preso em Foz do Iguaçu em 1970:

[...] que, em dita sala, novamente o interrogado foi submetido a torturas, já das mesmas participando o Capitão Júlio Mendes e o Tem. Expedito; que, após as sevícias já referidas, trouxeram um papel, ou melhor, vários papéis para que o interrogando assinasse; que, em face dos fatos já descritos, o interrogando se limitou às assinaturas, desconhecendo, no entanto, o conteúdo de tais papéis; [...]

$\mathrm{O}$ pânico e o medo provocado pelas sevícias levaram alguns réus a assinar os papéis que lhe apresentavam:

[...] que foi obrigado a assinar as páginas de fls. 62 a 74 face às declarações de alguns homens da P.E. de que, se não assinasse, teria de voltar para o primeiro Quartel em que esteve, onde sofreu maus tratos; [...] (Depoimento de João Luiz San Tiago Dantas Barbosa Quentel, 21 anos, estudante, Rio, 1973) (ARQUIDIOCESE DE SÃO PAULO, 1985, p. 208-209)

Em outros casos, o suicídio era a única solução para romper com o sofrimento psíquico evitar a delação dos companheiros. Um caso semelhante ocorreu com o estudante Manuel Domingos Neto, de 22 anos, natural de Fortaleza, em 1971,

Que, em virtude de todos esses maus-tratos recebidos, o interrogando passou a ingressar num estado de desespero, chegando mesmo a pensar em suicídio; que, a partir daí, os policiais passaram a ter o máximo de 
cuidado com o interrogando, evitando que o mesmo tomasse qualquer atitude extrema contra sua própria pessoa, pois constataram o estado de ânimo em que ele, interrogando, se encontrava; [...] que sobreveio, então, o esgotamento físico e mental ao interrogando, a ponto de ter este de ser hospitalizado no Hospital S.O.S. desta capital, onde passou dez dias inconsciente; que, depois, foi para o Hospital Militar, onde passou por um tratamento psiquiátrico durante quatro meses;[...] (ARQUIDIOCESE DE SÃO PAULO, 1985, p. 219)

Os transtornos psicológicos provocaram diferentes reações e, no caso do bancário Manoel Henrique Ferreira, de 21 anos, no Rio de Janeiro, ele relatou que:

[...] em mim, essas torturas tiveram ainda o papel de desestruturar psicologicamente. Elas levaram-me até o ponto de ir à televisão fazer um pronunciamento contra a luta da qual eu participava. Eu fui à televisão, fiz um pronunciamento negando minhas ideias, e fiz isto sob um estado completo de desestruturação por todas as torturas sofridas, por todas as ameaças e pelo medo que tinha de vir a ser morto. [...] (ARQUIDIOCESE DE SÃO PAULO, 1985, p. 221)

Fica evidenciado nos relatos que os castigos físicos infligidos não foram orquestrados por mentes doentias e subordinados rebeldes, ao contrário, tratava-se de uma atuação orgânica do Estado que operava com a participação de profissionais da saúde, entre eles, enfermeiros e médicos que burlavam os exames de "corpo-delito", as autópsias e ocultavam cadáveres, simulando versões para as mortes que ocorriam nas catacumbas aparelhos de repressão. Além dos presos políticos, muitos de seus familiares e amigos foram vitimados pela tortura naqueles tempos sombrios.

Em vista disso, pode inferir que o projeto "Brasil Nunca Mais" se caracteriza como um registro de memórias dos acontecimentos vistos pelos olhares dos opositores da ditadura militar no Brasil que imprimiram suas narrativas de acordo com seus lugares sociais e experiências políticas. Logo, ao produzirem as referidas narrativas, denunciaram a violência do Estado e sua classe dominante contra quaisquer inconformismos. Nesse sentido, é inegável que a síntese publicada em livro, bastante acessível, resgata e fixa uma memória insurgente contra o autoritarismo teoricamente embasado na Doutrina de Segurança Nacional (DSN). 


\section{O combate a "subversão" em "Brasil Sempre"}

Em "Brasil Sempre", publicação de 1986, escrita pelo tenente Marco Pollo Giordani, o autor se apresenta como um modesto homem do exército, de valores inabaláveis e a serviço da pátria, considerando-se possuidor da coragem, da determinação e da integridade de um homem de informações, com vários anos de DOI-CODI, dedicados, segundo o autor, a libertar o país da subversão. Giordani, aponta a publicação de "Brasil Nunca Mais" como uma das principais motivações para escrever seu livro. Porém, o autor esclarece que não é sua intenção contestar a obra "Brasil Nunca Mais”, justificando que esse ato seria tão insignificante quanto recomendá-la. Afirma, enfim, que sua real intenção é falar da parte esquecida pelo "Brasil Nunca Mais".

A respeito do tenente Marco Pollo Giordani, ressalta-se que como membro de baixa patente, integrou a $2^{a}$ Seção do Comando Militar do Sul, tendo se incorporado ao Exército em 1968, atuando durantes os anos mais árduos da repressão como agente do Destacamento de Operações de Informações do Centro de Operações de Defesa Interna (DOI-CODI). Segundo entrevista concedida pelo editor Airton Ortiz", responsável pela primeira edição de "Brasil Sempre", Giordani foi afastado do Exército por recomendação médica, fato que não acolheu bem.

"Brasil Sempre", nas palavras do escritor, se considera portador "da verdade e do consenso" e lamenta as manifestações contrárias aos "sublimes objetivos da Revolução de 1964". Posiciona-se contra a tortura, entretanto, considera que pela lei natural da vida cada ação remete a uma reação. Este posicionamento pode ser conferido em sua narrativa,

Antes de maiores considerações, devo deixar claro, que sou radicalmente contra torturas. Entendo que homens que lutam pela liberdade e que defendem a vida como Expressão-Maior da Criação não podem aviltar-se em práticas dessa natureza. Todo o meu ser se nega ao ato indigno e covarde da tortura. Digo isso com toda a sinceridade e com todo o orgulho. (GIORDANI, 1986, p. 95-96)

E ainda,

\footnotetext{
${ }^{6}$ A supracitada entrevista pode ser acessada por meio do endereço eletrônico: < $\underline{\text { https://gau- }}$ chazh.clicrbs.com.br/cultura-e-lazer/noticia/2014/09/Livro-de-agente-do-regime-militarBrasil-Sempre-sera-relancado-nesta-sexta-4603387.html.>
} 
Há no ordenamento da vida, uma lei fundamental: a cada ação, corresponde uma reação, ou, de acordo com o correto ditado popular: "quem semeia vento, colhe tempestade".

Antes de enunciar horrores e depoimentos histéricos, caberia a um sacerdote emitir a clássica indagação: que fizeste, filho? Que praticaste contra a vida de teus semelhantes, contra a comunidade que te abriga, contra as autoridades que, justas ou injustas, são constituídas?

- Ah! ... Sim! ... escolheste o caminho do sangue, da perfídia, da crueldade, e queres o conforto de uma ducha quente e a delícia de um "pãode-ló"? Que é isso, filho!?

Sim, essa seria a conduta adequada de um verdadeiro sacerdote, cuja missão é mostrar o caminho da verdadeira verdade libertadora. (GIORDANI, 1986, p. 97)

A narrativa de Giordani sugere não ter ele se envolvido diretamente com a prática da tortura, mas confirma a existência desse ato perverso no DOI-CODI e usa de artifícios morais e religiosos para condenar a defesa dos direitos humanos explicitada nas páginas do projeto "Brasil Nunca Mais" pelo cardeal Dom Evaristo Arns. Além disso, acusa a Igreja e os sacerdotes progressistas de descumprir a missão que os "homens de Deus" têm com o caminho da "verdade" e, por fim, considera a concessão da anistia aos terroristas um erro.

O perfil narrativo de Giordani é marcado pela defesa do lugar social de patriota e de "defensor da nação" que se via "aterrorizada" pelos opositores da ditadura. No decorrer de sua exposição o autor justifica que diante do perigo do Brasil ser "subtraído" pelo comunismo, o Estado entendeu a necessidade de estruturar órgãos especializados para combater o terror que vinha se alastrando,

Então, é preciso dizer que o chamado "Sistema Repressivo" montado pelo Estado (inicialmente a Operação Bandeirantes - OBAN - e posteriormente os CODI-DOIs, a nível nacional) para combater a guerrilha, nada mais foi do que o antídoto contra o veneno disseminado. (GIORDANI, 1986, p. 99)

Entretanto, a tortura é posta como consequência de excessos provocados pelo despreparo e/ou desvio moral de agentes ligados aos órgãos policiais,

É lógico o raciocínio de que os primeiros elementos formadores de tais órgãos - muitos deles oriundos de forças diferentes (Polícia Federal, Polícia Estadual) - não possuíam nem qualificação profissional e talvez nem a integridade moral para a importância de tal missão. Não quero co- 
meter injustiças nem tecer comentários irresponsáveis. Se houve excessos por parte desses pioneiros, há de merecer análise o fato de enfrentarem uma guerra suja, cruel, sem uniforme e sem distinção de vítimas. Se realmente houve sádicas torturas, não tenho o menor constrangimento de enquadrá-los no mesmo nível dos elementos da esquerda. Devo acrescentar, contudo, que as precipitações violentas originárias da própria luta são extremamente difíceis de serem julgadas. Não vivi aqueles elementos como membro dos referidos órgãos. (GIORDANI, 1986, p. 99)

Desse modo, Giordani ao articular tal narrativa se posiciona contra a tortura e justifica o seu uso durante a ditadura militar no Brasil, como excessos ocorridos em decorrência direta do combate a subversão. Nesta linha de pensamento, é verificável que ao lançar, publicamente, sua narrativa o autor proferiu recordações em salvaguarda própria e em "defesa da nação", amparando a "Revolução de 1964" como um ato obrigatório de preservar a "boa" imagem das Forças Armadas.

As inconsistências no pensamento de Giordani se explicam por serem elucubrações, sem nenhuma consistência factual, que demonstre a singularidade da tortura praticada por uns poucos agentes doentios e pioneiros na atuação do DOI-CODI. Esse órgão funcionou em todas as regiões do país durante todo o período da ditadura e há extensão documentação comprobatória de atos de tortura e a prática de assassinatos em toda existência. Cabe ressaltar que os relatos de tortura do "Brasil Nunca Mais" foram extraídos de processos correntes na Justiça Militar, portanto, documentos oficiais produzidos por uma instituição dentro da estrutura do Estado autocrático. Assim sendo, as memórias do tenente Giordani são subsidiadas por um conjunto de descrições sobre os fatos ocorridos que representam os interesses oficiais de ocultar e silenciar a atuação sistemática dos governos ditatoriais na prática da tortura.

$\mathrm{Na}$ ânsia de procurar esclarecer a "subversão", como um meio de obtenção o poder e, perseguindo questionamentos como "Por quê?", "Quê?", "Como?”, "Quando”, "Para quê?”, “Quem?” e "Onde?” o memorialista da ditadura traça uma reflexão enviesada sobre o pensamento comunista. Ele dissimula, deliberadamente, a existência de religiosos, crianças, conservadores que jamais militaram ou se declararam comunistas e, ainda assim, foram submetidos à tortura nos porões das unidades em São Paulo, no Rio de Janeiro e em Recife.

Por fim, cabe ressaltar que mesmo os exércitos regulares, em tempos de guerra, têm códigos de conduta no trato com prisioneiros e inimigos mortos. $\mathrm{O}$ desaparecimento de centenas de pessoas, após serem submetidas às torturas, demonstra que os oficiais das Forças Armadas, responsáveis pelos interrogató- 
rios, ocultaram cadáveres e descumpriram uma infinidade de dispositivos legais existentes no Brasil e no exterior.

Assim sendo, pode-se concluir que os combates pela memória sobre a ditadura militar opõem classes sociais distintas que se conflitam diante da necessidade de perpetuar versões sobre o passado. As lembranças preteridas não são meros recursos cognitivos, ao contrário, estabelecem relações com o presente e determinam, inclusive, o modus operandi dos grupos dominantes sobre o conjunto da sociedade.

\section{Referências}

ALVES, M. H. M. Estado e Oposição no Brasil (1964-1984). $5^{\text {a }}$ ed., Petrópolis: Vozes, 1989.

ARQUIDIOCESE DE SÃO PAULO. Brasil Nunca Mais. Petrópolis: Editora Vozes, 1985.

BRASIL, Escola Superior de Guerra. Manual Básico. Rio de Janeiro: ESG, 1992.

CHAUI, Marilena. Manifestações ideológicas do autoritarismo brasileiro. Organizador André Rocha. Belo Horizonte: Autêntica Editora/São Paulo: Editora Fundação Perseu Abramo, 2013.

COMBLIN, J. A Ideologia de Segurança Nacional. Rio de Janeiro: Editora Civilização Brasileira S.A., 1978.

DIAS, J. A. Memória e Ideologia: a tortura como mecanismo de silenciamento durante a ditadura militar no Brasil. In: CARDOSO, L. C.; CARDOSO, C. C. (org.). Ditadura: memória, violência e silenciamento. Salvador: EDUFBA, 2017.

DREIFUSS, R. A.; DULCI, O. S. As Forças Armadas e a Política. In: . Sociedade e Política no Brasil Pós-64. 2. ed., São Paulo: Brasiliense, 1984, p. 87117.

FENTRESS, J.; WICKHAM, C. Memória Social: novas perspectivas sobre o passado. Lisboa: Editorial Teorema, 1992.

FERNANDES, F. A ditadura em questão. São Paulo: T.A. Queiroz, 1982. GIORDANI, M. P. Brasil Sempre. Porto Alegre: Tchê! Editora Ltda, 1986. HALBWACHS, M. A Memória Coletiva. São Paulo: Editora Centauro, 2006. . Los Marcos Sociales de La memoria. Postfacio de Gérard Namer; traducción de Manuel A. Baeza y Michel Mujica. - Rubí (Barcelona): 
Anthropos Editorial; Concepción: Universidade de la Concepción; Caracas: Universidade Central de Venezuelas, 2004.

JELIN, E. Los trabajos de la memoria. Madrid: SSRC, 2002;

MAINWARING, S. Igreja e política: anotações teóricas. Síntese Revista de Filosofia, Belo Horizonte: FAJE, v.10, n. 27, 1983.

MARQUES, A. S. M. A Organização Latino Americana de Solidariedade (OLAS) e o embate ideológico na esquerda brasileira, 1960: o caso PCB. 2009. Dissertação (Mestrado em Integração Latino-Americana) - Universidade Federal da Santa Maria, Santa Maria, 2009.

MARTINS FILHO, J. R. Movimento estudantil e militarização do Estado no Brasil (1964-1968). 1986. (Dissertação (Mestrado Ciência Política) IFCH - Unicamp, Campinas, 1986.

OLIVEIRA, E. R. de. As Forças Armadas: Política e Ideologia no Brasil (1964-1969). Petrópolis: Vozes, 1976.

PERALTA, E. Abordagens teóricas ao estudo da memória social: uma resenha crítica. Arquivos da Memória - Antropologia, Escala e Memória, Centro de Estudos de Etnologia Portuguesa, Lisboa, n 2 (nova série), p. 4-23, 2007. 